DOI 10.31558/2518-7953.2019.2.17

УДК 349:412 (477)

А. Г. Бобкова, професор кафедри господарського права Донецького національного університету імені Василя Стуса, доктор юридичних наук, професор, академік НАПрН України

С. О. Липницька, в. о. завідувача кафедри господарського права Донецького національного університету імені Василя Стуса, кандидат юридичних наук

\title{
ЗДІЙСНЕННЯ ПРАВА ВЛАСНОСТІ НА ЗЕМЛЮ ОРГАНАМИ ДЕРЖАВНОЇ ВЛАДИ ТА МІСЦЕВОГО САМОВРЯДУВАННЯ ВІД ІМЕНІ УКРАЇНСЬКОГО НАРОДУ
}

Ключові слова: земля, Український народ, право власності, органи державної влади, органи місиевого самоврядування, начіональне багатство, повноваження.

Земля є унікальним природним ресурсом, складовою національного природного багатства, що охоплює грунти та інші природні елементи ландшафту, які взаємопов'язані між собою і забезпечують належне функціонування флори та фауни, а також життєдіяльність людини та розвиток суспільства. 3 урахуванням особливої цінності цього ресурсу для країни на рівні Основного Закону визначено, що земля в межах території України є основним національним багатством, що знаходиться у власності Українського народу. При цьому використано імперативний принцип особливої охорони цього важливого об'єкта природи.

Однак, як показують останні події, при прийнятті законодавчих актів іноді нехтуються конституційні положення щодо здійснення права власності Українського народу на землю. У Верховній Раді України зареєстровано низку законопроєктів щодо внесення змін до деяких законодавчих актів України щодо обігу земель сільськогосподарського призначення, один 3 яких (№ 2178-10 від 10.10.2019 р.) вже прийнято за основу і готується до другого читання [1]. Аналіз цього законопроєкту дає підстави стверджувати, що суб'єктом законодавчої ініціативи взято до уваги далеко не всі конституційні принципи, що є доктриналь- 
ними настановами, які обумовлюють стратегію регулювання земельних відносин в Україні і формування земельного законодавства. Водночас вирішення питання власності на землю і іiі здійснення $є$ і питанням національної безпеки, на чому наголошується в Аналітичній записці «Ринок землі: існуючі загрози для України та необхідні запобіжники», підготовленій GROWFORD Institute, де зазначено, що, з огляду на загрозливі глобальні процеси, які відбуваються сьогодні, продовольча безпека і збереження Україною власності на свою землю є питанням рівня національної безпеки [2]. При цьому найбільше проблем на практиці стосується здійснення права власності на землю Українського народу, до чого безпосереднє відношення мають органи державної влади і місцевого самоврядування.

Вирішення питань права власності на землю тісно пов’язане з тлумаченням на законодавчому рівні поняття землі як об’єкта права власності Українського народу, основного національного багатства, що перебуває під особливою охороною держави в контексті ч. 1 ст. 13 та ч. 1 ст. 14 Конституції України. Таке тлумачення сьогодні викликає суперечливі підходи як в доктрині земельного права, так і в судовій практиці (зокрема на рівні Конституційного Суду України), що може поставити під сумнів відповідність Основному Закону будь-якого з прийнятих законопроєктів, тим більше, що вказані конституційні положення непослідовно втілені в Земельний кодекс України як базовий нормативно-правовий акт земельного законодавства.

Проблеми здійснення права власності народу України на землю є постійно в центрі уваги науковців, зокрема грунтовні дослідження проведено В. В. Носіком, В. І. Андрейцевим, А. М. Мірошниченко, I. І. Каракашем, I. I. Семчиком, I. О. Костяшкіним та іншими авторами. Водночас питання участі у здійсненні цього права органів державної влади і місцевого самоврядування продовжують залишатися дискусійними, що зумовлено як активізацією законотворчого процесу щодо обігу земель сільськогосподарського призначення, так і іншими чинниками, 3-поміж яких формування нових підходів до вирішення судових спорів Верховним Судом, позиція Міжнародного валютного фонду стосовно розвитку ринку землі в Україні тощо.

Вищенаведене вказує на актуальність обраної теми дослідження, метою якого є обтрунтування напрямів удосконалення здійснення права власності на землю органами державної влади та місчевого самоврядування від імені Українського народу.

Для досягнення цієї мети потребує з'ясування зміст поняття «земля» в контексті ч. 1 ст. 13 Конституції України, де закріплено, що земля, яка знаходиться в межах території України, є об’єктом права власності Українського народу [3].

У законодавстві поняття «земля» тлумачиться як поверхня суші з грунтами, корисними копалинами та іншими природними елементами, що органічно поєднані та функціонують разом з нею (ст. 1 Закону України «Про охорону земель») [4]. 
У доктрині земельного права заявлено різні підходи до змісту поняття «земля». Наприклад, М. В. Шульга визначає землю як найважливішу складову частину навколишнього природного середовища, що є частиною земної кори, яка $є$ просторовою основою ландшафту, розташованою над надрами, що використовується як засіб виробництва в сільському та лісовому господарстві або як місце розташування різноманітних об'єктів [5, с. 161].

Інший підхід до визначення поняття «земля» застосовано авторами Науковопрактичного коментаря до Земельного кодексу України, а саме: поняття «земля» вживається в розумінні земної поверхні та простору над та під нею на висоту та глибину, необхідні для використання земельної ділянки за цільовим призначенням (зокрема забудови), з грунтовим покривом у межах цього простору включно [6, с. 17].

Водночас наведені позиції науковців, а також нормативні визначення недостатньо повно відбивають юридичні властивості землі саме як об'єкта права власності Українського народу.

Ознаки землі як об'єкта права власності Українського народу запропоновано В. І. Андрейцевим. На його думку, поняття «земля» має розумітися як головна територіально просторова частина довкілля (навколишнього природного середовища) у межах території України, національне багатство Українського народу, матеріальна основа територіальної цілісності, суверенітету і національної безпеки держави [7, с. 14].

Найбільш повне визначення землі як об’єкта права власності Українського народу запропоновано В. В. Носіком, а саме: «це розташований над надрами, територіально обмежений кордонами України, цілісний, нерухомий поверхневий грунтовий і зайнятий природними ресурсами шар, який є основою ландшафту i просторовим базисом для гармонійного розподілу місць розселення, діяльності людей, об’єктів природно-заповідного фонду з урахуванням економічних, соціальних, екологічних та інших інтересів суспільства, що належить Українському народу на праві власності і підлягає особливій охороні з боку держави як основне національне багатство» [8, с. 6].

Наведені визначення вказують на стратегічний характер такого ресурсу як земля для України і відповідають проголошеним у Декларації про державний суверенітет України положенням, що земля є власністю народу України, матеріальною основою суверенітету Республіки і використовується з метою забезпечення матеріальних та духовних потреб іï громадян [9].

Однією з ключових ознак землі як об'єкта права власності Українського народу, врахування якої впливає на дослідження питань здійснення права власності на землю Українського народу, є віднесення ії до основного національного багатства. Національне багатство - один із головних показників економічного 
стану держави, сукупність матеріальних благ і духовних цінностей, нагромаджених суспільством за всю його історію. До складу національного багатства входять природні ресурси країни (розвідані й нерозвідані поклади корисних копалин, земля, ліси, води та ін.), а також виробничий і науково-технічний потенціал населення, його культурно-освітній рівень тощо [10].

На доктринальному рівні визнано, що сутність основного багатства полягає в тому, що серед усіх природних об’єктів права власності народу, серед усіх категорій має бути визначений такий компонент, який є найважливішим у забезпеченні права людини на життя, розвиток економіки, суспільства, достатку кожного громадянина, реалізації конституційних прав і свобод. Таким компонентом $\epsilon$ земля як складова біосфери, що охоплює грунти та інші природні елементи ландшафту, які органічно пов'язані між собою і забезпечують належне функціонування флори та фауни, життєдіяльності людини та розвиток суспільства.

Визнання землі національним багатством обумовлює поєднання таких особливостей використання землі, як-от: 1) територіального базису знаходження (проживання) народу, 2) природного репродуктивного ресурсу, 3) основного засобу виробництва, і вказує на значення землі для країни.

Визнання землі основним національним багатством впливає на створення для неї особливого правового режиму охорони і використання, що й передбачено ч. 1 ст. 14 Конституції України та ст. 2 Закону України «Про охорону земель». Зазначене конституційне положення обумовлює основні засади регулювання земельних відносин як у сучасних умовах, так у перспективі, передусім при вирішенні питань здійснення права власності на землю органами державної влади та місцевого самоврядування.

Особливий правовий режим землі покладає на органи державної влади, а також місцевого самоврядування обов' язок забезпечити регулювання раціонального використання та охорони земель. Виконання цього обов'язку забезпечується здійсненням вказаними органами низки функцій управління землями, спрямованих на охорону земельних ресурсів, а також шляхом визначення правового режиму різних категорій земель.

Під правовим режимом земель розуміється особливий порядок правового регулювання поведінки учасників суспільних відносин у галузі використання та охорони земель, а також управління земельними ресурсами, що виражається в поєднанні юридичних засобів, спрямованих на забезпечення раціонального використання та охорони земель в інтересах всього суспільства і конкретних землевласників та землекористувачів [11].

На підтвердження того, що землі підлягають особливій охороні, свідчать й інші норми Конституції України (ч. 2 ст. 14, п.п. 5, 7 ч. 1 ст. 92), що закріплюють за Верховною Радою України виключне право законодавчого регулювання всіх 
відносин стосовно використання природних ресурсів і встановлення правового режиму власності, зокрема права власності на землю. На це вказує також рішення Конституційного Суду України від 22 вересня 2005 р. № 5-рп/2005 (справа про постійне користування земельними ділянками) [12].

Відповідним проявом особливої охорони землі є також те, що суб'єктивне право власності на землю передбачає наявність встановлених законодавством обов'язків власників земельних ділянок, а також обмежень у здійсненні права власності аж до припинення права власності. Можливість обмеження реалізації права власності на землю в Україні безпосередньо випливає із положень Основного Закону, а саме: ст. 1 - Україна є соціальною державою; ч. 3 ст. 13 - «Власність зобов'язує. Власність не повинна використовуватися на шкоду людині і суспільству»; ч. 7 ст. 41, якою передбачено, що використання власності не може завдавати шкоди правам, свободам та гідності громадян, інтересам суспільства, погіршувати екологічну ситуацію та природні якості землі.

Отже, удосконалення правових засад щодо здійснення права власності на землю Українського народу органами державної влади та місцевого самоврядування потребує врахування належності землі до національного багатства.

Наступним питанням, що потребує з'ясування для досягнення мети цього дослідження, є поняття «Український народ», щодо якого також постійно точаться дискусії. Народ визначається як спільнота, що складається з пов'язаних спільним громадянством індивідів, які мають первинні права щодо держави [13, c. 34]. У положеннях Конституції України прямо визначено, що Український народ- це громадяни всіх національностей, носій суверенітету, єдине джерело влади, суб'єкт права власності на землю та інші природні ресурси (преамбула, ст.ст. 5, 13 Конституції України).

Автори науково-практичного коментаря Основного Закону дійшли висновку, що «науково-теоретичний аналіз закріплених у Конституції України імперативів показує, що ст. 13 закріплює юридичну модель здійснення права власності на землю та інші природні ресурси Українського народу, суть якої полягає в тому, що ці об'єкти навколишнього природного середовища в межах території України, її континентального шельфу та виключної морської (економічної) зони є об’єктами права власності Українського народу, який є самостійним суб'єктом права власності на зазначені об’єкти. Український народ може у визначених Основним Законом держави формах і межах безпосередньо здійснювати правомочності володіння, користування і розпорядження землею та іншими природними ресурсами або ж від його імені права власника на них можуть здійснювати уповноважені органи державної влади та місцевого самоврядування. Оригінальність закладених у Конституцію України правових ідей щодо здійснення права власності на природні ресурси Українського народу базується на сучасному науковому 
сприйнятті об'єктів довкілля в системному зв'язку: земля-людина-суспільствоприрода» [13, с. 96].

Таке тлумачення заслуговує на увагу, однак для його використання при удосконаленні положень земельного законодавства щодо здійснення права власності Українського народу необхідно більш детальне бачення поняття «Український народ», особливо з урахуванням інших положень Конституції України, зокрема ст. 13.

Ст. 13 Конституції України закріплено, що від імені Українського народу права власника здійснюють органи державної влади та органи місцевого самоврядування в межах, визначених цією Конституцією. Перелік органів державної влади та органів місцевого самоврядування, уповноважених здійснювати право власності Українського народу на землю, можна визначити, спираючись на положення ст. 19 Конституції України, інших статей Основного Закону, положення Земельного кодексу України та інших чинних законодавчих актів. При цьому межі здійснення права власності від імені Українського народу встановлені Конституцією України (ч. 1 ст. 13 Основного Закону). Водночас дослідниками висловлюється думка щодо необхідності чіткого розмежування повноважень відповідних органів, які в окремих випадках, реалізуючи управлінські функції у сфері земельних відносин, представляють Український народ, що потребує абсолютно різного підходу при визначенні та забезпеченні правового режиму земель незалежно від форми власності [14, с. 210], з чим варто погодитися.

Окремої уваги заслуговує питання віднесення Верховної Ради України до органів, які здійснюють право власності на землю від імені Українського народу. Положення ст. 5 Конституції України, згідно з якою народ України виступає єдиним джерелом влади в Україні, який діє безпосередньо або через органи державної влади та органи місцевого самоврядування, разом 3 іншими положеннями Основного Закону дають підстави стверджувати, що саме народ наділений усією повнотою влади і через форми прямої та опосередкованої демократії може реалізовувати правомочності власника.

Окрім цього, положення Конституції України дають змогу дійти висновку, що єдиним суб'єктом, який діє від імені Українського народу щодо всіх його правомочностей власника землі та інших природних ресурсів в межах території держави, їі континентального шельфу і виключної (морської) економічної зони, виступає Верховна Рада України [13, с. 96]. Зміст ст. 6 та інших статей Земельного кодексу України підтверджує висловлену позицію та дає змогу з нею погодитися.

Отже, правомочності власника від імені Українського народу на вищому рівні відносин власності на землю має Верховна Рада України, яка у межах, визначених Конституцією України, встановлює правовий режим усіх категорій земель, 
тобто приймає рішення щодо володіння, користування і розпорядження землею у «глобальному» розумінні. Інші органи державної влади та органи місцевого самоврядування у межах, встановлених Конституцією України, забезпечують реалізацію Українським народом правомочностей власника щодо певних категорій земель, що і охоплюється поняттям «здійснення права власності».

Одним із найбільш дискусійних питань щодо здійснення права власності на землю Українського народу є розмежування повноважень безпосередньо Українського народу і органів державної влади та місцевого самоврядування, яким відповідно до ст. 13 Конституції України надано повноваження від імені Українського народу здійснювати права власника в межах, визначених Конституцією.

При застосуванні цієї статті Конституції у судовій практиці все ще не завжди враховується те, що буквальне тлумачення цього положення Конституції України дає підстави для висновку, що органи державної влади і місцевого самоврядування наділені від імені Українського народу не правом власності на землю, а правом на здійснення права власності, тобто вони забезпечують реалізацію конституційних положень щодо прав власника на землю від імені Украӥнського народу.

Для уточнення правових засад здійснення права власності на землю органами державної влади і місцевого самоврядування доцільно звернутися до ч. 2 ст. 19 Конституції України, за якою «органи державної влади та органи місцевого самоврядування, їхні посадові особи зобов’ язані діяти лише на підставі, в межах повноважень та у спосіб, що передбачені Конституцією та законами України», що рівною мірою стосується і земельних відносин. При цьому згідно з ч. 1 ст. 2 Земельного кодексу України земельні відносини - це суспільні відносини щодо володіння, користування і розпорядження землею. Суб'єктами земельних відносин $є$ громадяни, юридичні особи, органи місцевого самоврядування та органи державної влади.

Водночас на законодавчому рівні відсутнє врахування того, що органи державної влади і місцевого самоврядування здійснюють повноваження власника як від імені Українського народу, так і від відповідних власників землі конкретної форми власності, що випливає зі ст. 80 Земельного кодексу України, за якою «суб'єктами права власності на землю є: ... б) територіальні громади, які реалізують це право безпосередньо або через органи місцевого самоврядування, - на землі комунальної власності; в) держава, яка реалізує це право через відповідні органи державної влади, - на землі державної власності».

3 урахуванням загальновідомого визначення поняття права власності до повноважень органів державної влади та органів місцевого самоврядування як органів, щзо здійснюють права власника від імені Украӥнського народу, можна віднести: 1) повноваження, що здійснюються від імені всього Українського народу (Верховна Рада України); 2) повноваження, що здійснюються від імені кількох 
територіальних громад (обласні і районні ради щодо спільної власності відповідних територіальних громад); 3) повноваження, що здійснюються від імені конкретних територіальних громад (сільські, селищні, міські ради); 4) повноваження, що здійснюються органами державної влади від імені Українського народу (центральний орган виконавчої влади, що забезпечує формування державної політики у сфері земельних відносин; державні органи приватизації у галузі земельних відносин тощо).

Наприклад, до повноважень Верховної Ради України як органу, щзо здійснює права власника на землю Украӥнського народу, відповідно до п. 3 ч. 1 ст. 85 Конституції України належить прийняття законів, зокрема у сфері земельних відносин. Конкретизовано цю норму ст. 6 Земельного кодексу України, за якою до повноважень Верховної Ради України в галузі земельних відносин належить: а) прийняття законів у галузі регулювання земельних відносин; б) визначення засад державної політики в галузі використання та охорони земель; в) затвердження загальнодержавних програм щодо використання та охорони земель; г) встановлення і зміна меж районів і міст; д) погодження питань, пов'язаних зі зміною цільового призначення особливо цінних земель державної та комунальної власності, припиненням права постійного користування ними відповідно до цього Кодексу; е) вирішення інших питань у галузі земельних відносин відповідно до Конституції України.

До повноважень обласних рад у галузі земельних відносин на території області як органу, щзо здійснює права власника на землю Українського народу відповідно до п. «а» ч. 1 ст. 8 Земельного кодексу України належить розпорядження землями, що знаходяться у спільній власності територіальних громад.

До повноважень Київської і Севастопольської міських рад у галузі земельних відносин на їхній території як органів, щзо здійснюють права власника на землю Украӥнського народу, відповідно до ст. 9 Земельного кодексу України належить: а) розпорядження землями територіальної громади міста; б) передача земельних ділянок комунальної власності у власність громадян та юридичних осіб відповідно до цього Кодексу; в) надання земельних ділянок у користування із земель комунальної власності відповідно до цього Кодексу; г) вилучення земельних ділянок із земель комунальної власності в порядку, передбаченому цим Кодексом; д) викуп земельних ділянок для суспільних потреб міста; е) припинення права користування земельними ділянками у випадках, передбачених цим Кодексом; ж) прийняття рішення щодо звільнення самовільно зайнятих земельних ділянок; и) підготовка висновків щодо вилучення (викупу) та надання земельних ділянок із земель державної власності, що проводяться органами виконавчої влади.

До повноважень районних рад у галузі земельних відносин на території району як органу, щзо здійснює права власника на землю Украӥнського народу, відпо- 
відно до ст. 10 Земельного кодексу України належить розпорядження землями на праві спільної власності відповідних територіальних громад.

До повноважень сільських, селищних, міських рад у галузі земельних відносин на території сіл, селищ, міст як органів, щзо здійснюють права власника на землю Українського народу, відповідно до ст. 12 Земельного кодексу України належить: а) розпорядження землями територіальних громад відповідно до цього Кодексу; б) надання земельних ділянок у користування із земель комунальної власності відповідно до цього Кодексу; в) вилучення земельних ділянок із земель комунальної власності відповідно до цього Кодексу; г) викуп земельних ділянок для суспільних потреб відповідних територіальних громад сіл, селищ, міст.

До повноважень центрального органу виконавчої влади, що забезпечує формування державної політики у сфері земельних відносин як органу здійснення права власності на землю Украӥнського народу, відповідно до ст. 15 Земельного кодексу України належать: здійснення нормативно-правового забезпечення у сфері земельних відносин; забезпечення проведення земельної реформи; розроблення економічного механізму регулювання земельних відносин; участь у розробленні заходів щодо розвитку ринку земель.

До повноважень центрального органу виконавчої влади, що реалізує державну політику у сфері земельних відносин як органу здійснення права власності на землю Українського народу, відповідно до ст. $15^{-1}$ Земельного кодексу України належить: внесення в установленому порядку пропозицій щодо розпорядження землями державної та комунальної власності; організація проведення робіт, пов'язаних із реалізацією земельної реформи.

Окремі повноваження щодо здійснення права власності Українського народу мають і інші органи державної влади відповідно до Земельного кодексу України.

Водночас зазначені повноваження органів державної влади потрібно відрізняти від повноважень цих органів у разі здійснення ними права власника на землю державної форми власності відповідно до ст. 80 Земельного кодексу України. Зокрема до повноважень Кабінету Міністрів України в галузі земельних відносин відповідно до ст. 13 Земельного кодексу України належить: розпорядження землями державної власності в межах, визначених цим Кодексом; викуп земельних ділянок для суспільних потреб у порядку, визначеному законом.

До повноважень центрального органу виконавчої влади, що реалізує державну політику у сфері земельних відносин, відповідно до ст. $15^{-1}$ Земельного кодексу України належить розпорядження землями державної власності в межах, визначених цим Кодексом.

До повноважень місцевих державних адміністрацій у галузі земельних відносин відповідно до ст. 17 Земельного кодексу України належить: розпорядження землями державної власності в межах, визначених цим Кодексом. 
У таких відносинах, як це випливає із ст. 80 Земельного кодексу України, держава в особі органів державної влади і територіальні громади в особі органів місцевого самоврядування виступають рівноправними з іншими власниками (користувачами) суб'єктами земельних відносин, якщо їхнє право на земельну ділянку набуто у порядку, встановленому законом.

На це вказує і п. «б» ч. 1 ст. 5 Земельного кодексу України, що закріплює принципи земельного законодавства, серед яких «забезпечення рівності права власності на землю громадян, юридичних осіб, територіальних громад та держави».

Отже, органи державної влади і органи місцевого самоврядування при їхній участі у відносинах права власності на землю здійснюють права власника як від імені Українського народу як власника землі, так і відповідно органи державної влади - від імені держави як власника стосовно земель державної власності та органи місиевого самоврядування від імені територіальної громади чи кількох громад як власника(ків) стосовно земель, щзо належать таким громадам. Водночас, оскільки питання розмежування повноважень органів державної влади і місцуевого самоврядування щуодо здійснення права власності Украӥнського народу викликають проблеми на практиці, зокрема судовій, то вони потребують уточнення на законодавчому рівні.

Напрямами удосконалення здійснення права власності на землю органами державної влади та місиевого самоврядування від імені Украӥнського народу можна запропонувати:

законодавче уточнення з урахуванням напрацювань у доктрині земельного права визначення поняття «земля» як об'єкта права власності Украӥнського народу, громадян та юридичних осіб, територіальних громад та держави;

підтвердження визнання Українського народу власником землі иляхом приведення у відповідність до Конституції України норм Земельного кодексу України, а саме доповнення ст. 80 відповідними положеннями;

проведення розмежування за обсягом прав і обов'язків як власників поміж Украӥнським народом, конкретними громадянами, юридичними особами, територіальними громадами та органами здійснення права власності- органами державної влади і місчевого самоврядування без дублювання їхніх прав та обов 'язків;

виокремлення повноважень Кабінету Міністрів Украӥни, інших органів державної влади щуодо здійснення права власності Украӥнського народу $і$ здійснення права власності держави.

Подальші дослідження доцільно спрямувати на конкретизацію зазначених напрямів удосконалення здійснення права власності на землю органами державної влади та місцевого самоврядування від імені Українського народу. 
1. Проект Закону про внесення змін до деяких законодавчих актів України щодо обігу земель сільськогосподарського призначення (реєстр. № 2178-10 від 10.10.2019). Інформаційнопошукова система «Законодавство Украӥни». URL: https://w1.c1.rada.gov.ua/pls/zweb2/webproc4_1?pf3511=67059

2. Аналітична записка «Ринок землі: існуючі загрози для України та необхідні запобіжники. URL: http://growford.org.ua

3. Конституція України: Прийнята на п'ятій сесії Верховної Ради України 28 червня 1996 р. Відомості Верховної Ради України. 1996. № 30. Ст. 141.

4. Про охорону земель: Закон України від 19 червня 2003 р. № 962-IV. Інформаційнопошукова система «Законодавство Украӥни». URL: https://zakon.rada.gov.ua/laws/show/962-15

5. Носік В. В. Право власності на землю Українського народу: моногр. Юрінком Інтер, 2006. 544 c.

6. Мірошниченко А. М., Марусенко Р. І. Науково-практичний коментар до Земельного кодексу України. 3-те вид. Київ: Алерта; ЦУЛ, 2011. 516 с.

7. Андрейцев В. І. Об'єкти земельних правовідносин за новим Земельним кодексом України. Науково-практичні коментарі. 2002. № 2. С. 3-19.

8. Носік В. В. Проблеми здійснення права власності на землю Українського народу: автореф. ... д-ра юрид. наук спец. 12.00 .06 - земельне право; аграрне право; екологічне право. Київ: Київський нац. ун-т ім. Тараса Шевченка, 2007. 34 с.

9. Декларація про державний суверенітет України від 16.07.1990 р. Інформаційно-пошукова система «Законодавство України». URL: https://zakon.rada.gov.ua/laws/show/55-12

10. Нагребельний В. П. Юридична енциклопедія. В 6-ти т. / редкол.: Ю. С. Шемшученко (голова редкол.) та ін. Київ: «Укр. енцикл.», 1998, 670 с.

11. Сидор В. Д. Правовий режим земель в земельному законодавстві України. Адвокат. 2010. № 8. URL: http://irbis-nbuv.gov.ua

12. Рішення Конституційного Суду України № 5-рп/2005 від 22.09.2005 р. у справі за конституційним поданням 51 народного депутата України щодо відповідності Конституції України (конституційності) положень статті 92, пункту 6 розділу $\mathrm{X}$ «Перехідні положення» Земельного кодексу України (справа про постійне користування земельними ділянками). Iнформаційно-пошукова система «Законодавство України». URL: https://zakon.rada.gov.ua/laws/ show/v005p710-05

13. Конституція України. Науково-практичний коментар / редкол.: В. Я. Тацій (голова редкол.), О. В. Петришин (відп. секретар), Ю. Г. Барабаш та ін.; Нац. акад. прав. наук України. Харків: Право, 2011. 1128 с.

14. Костяшкін I. О. Окремі аспекти реалізації права власності на землю Українського народу. Університетські наукові записки. 2017. № 63. С. 204-214. 